\title{
Computer simulation of the load test of an extrusion blow moulded product
}

\author{
Michat Modławski ${ }^{*},{ }^{,}$, Jacek Nabiałek ${ }^{1}$, Tomasz Jaruga ${ }^{1}$ \\ ${ }^{1}$ Department of Polymer Processing, Czestochowa University of Technology, Armii Krajowej 19c, \\ 42-201 Częstochowa, Poland
}

\begin{abstract}
The results of compression "top load" test of an extrusion blow moulded container, performed in ANSYS Mechanical software, were presented. The nonuniform wall thickness of the blown product was considered because the thickness distribution was the result of the first step of the simulation in ANSYS Polyflow - the simulation of the product manufacturing by extrusion blow moulding. The hydrostatic pressure factor was taken into account during the "top load" simulation, because such a test is usually done for filled products. It was found that the biggest stress values occur around the inlet as well as in the side walls of the container.
\end{abstract}

Keywords: extrusion blow moulding simulation, top load test

\section{Introduction}

Extrusion blow moulding technology is used for many years, but because of the growing demand on plastics packagings in the last years this process is developing fastly, which is remarkable not only by increasing number of machines working in the industry but also by increasing the technological innovations [1].

Although the simulation of injection moulding process is widespread today, the simulation of blow moulding is still not used so much. The results of this simulation could contribute to the improvement in new products development thanks to the possibility of design modification at the product design stage. The computer simulation gives also an useful information about the processing parameters efficiency which is important while designing a product and a mould, that means before taking the costs of building a tool.

The research works regarding the computer simulation of extrusion blow moulding done so far were mainly about wall thickness distribution optimization [2-10], by controlling the extruded parison wall thickness distribution, for example. It is not only possible to optimize the wall thickness distribution, but also to reduce the mass of the product, using a computer simulation as a tool [7]. The processing conditions like blowing pressure, parison temperature or its wall thickness have a big impact on products' properties and on their quality. However, not all quality factors can be simulated nowadays - for example the surface roughness of a product and the degree of cavity mapping. These factors are an important quality indicators and they highly depend on processing parameters [11].

\footnotetext{
* Corresponding author: modlawski@ipp.pcz.pl

Reviewers: Kateryna Kravchenko, Ján Vavro
} 
The modeling of the product strength [8-10] with the reference to the results of blow moulding computer simulation is especially important because it allows modifying product design and processing conditions to obtain the required strength. The wall thickness distribution result should be used to simulate the strain and stress of the loaded container or to simulate the stress in the case of free fall of the container which occurs during the typical "drop test" of such products [10].

A canister-type container is one of typical extrusion blow moulded products. This product is specific due to its cubicoidal shape which makes the risk to thin the wall significantly in the corners during the moulding process as well as due to the handle used for carrying, but also being problematic during moulding [12-13].

\section{Simulation research}

The aim of this article was to determine the stress and strain distribution in a canister-type product, during the compression test, using a computer simulation. This product should be manufactured from high-density polyethylene, in an extrusion blow moulding process. The canister was loaded with the concentrated force of $100 \mathrm{~N}$, coming from the palletization of the filled products during their storage and transport, and loaded with the hydrostatic pressure. The computer simulation of the extrusion blow moulding process was done using ANSYS Polyflow software. The stress and strain distribution was simulated using ANSYS Mechanical software which was convenient to use in this case because of the possibility to transfer the data of manufacturing simulation from ANSYS Polyflow.

\subsection{The project of the canister}

The canister was designed in Siemens NX 8.5 CAD software. The following assumptions regarding the design and dimensions of this container were made:

- the canister volume is no less than 51 . The level of the free surface of the filling liquid should be below the neck,

- easy demoulding of the product is possible because the surfaces paralell to the mould opening direction are rounded, except of the upper surface of the handle, which is flat, and except of the bottom surface of this container,

- the side walls of the canister are flat; in these places usually labels are placed,

- there are no geometrical elements making canister more stiff (increasing its strength) except of the bottom,

- the bottom of the canister is of the shape which enables the canister to be put on a flat surface and increasing the strength of this product,

- the inlet was extended and evened with the top surface of the handle (as the cap height). The thread was neglected to simplify the shape used in the computer simulation.

The designed shape of the canister is presented in Fig. 1 with its main dimensions. The shape of this container is symmetrical so only a half of the canister was assumed in the blow moulding process and mechanical strength simulation. 


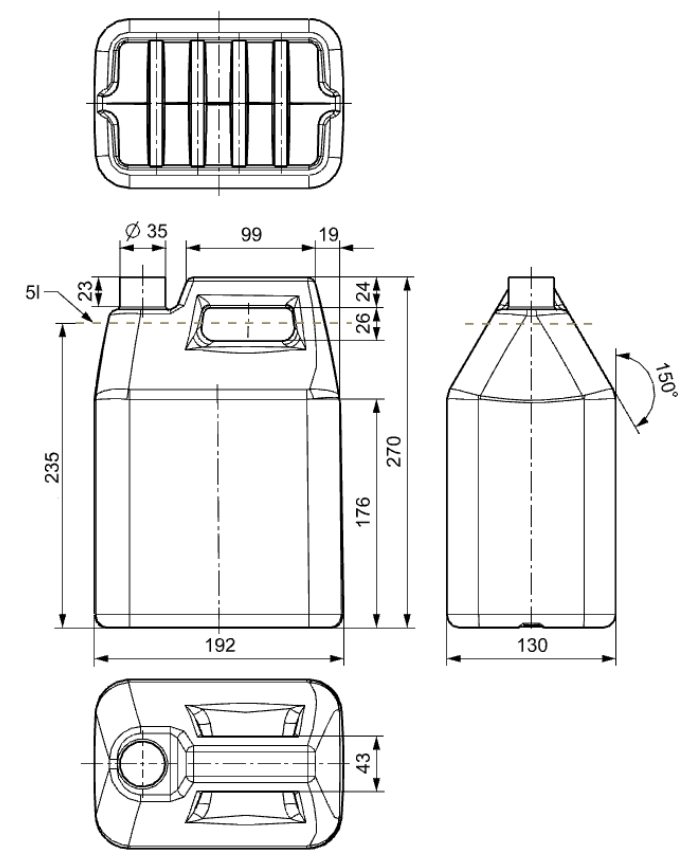

Fig. 1. The shape and main dimensions of the canister

\subsection{Blow moulding computer simulation}

During the blow moulding process simulation 1 second time of this process was considered. In this time the mould is closed with the velocity of $0.2 \mathrm{~m} / \mathrm{s}$ (from 0 to $0.4 \mathrm{~s}$ ) and after that the parison is blown by the gas overpressure in the time interval from 0.4 to $1.0 \mathrm{~s}$. The assumed value of the gas overpressure increases between 0.4 and $0.5 \mathrm{~s}$ time and reaches the value of 0.4 MPa (Fig. 2).
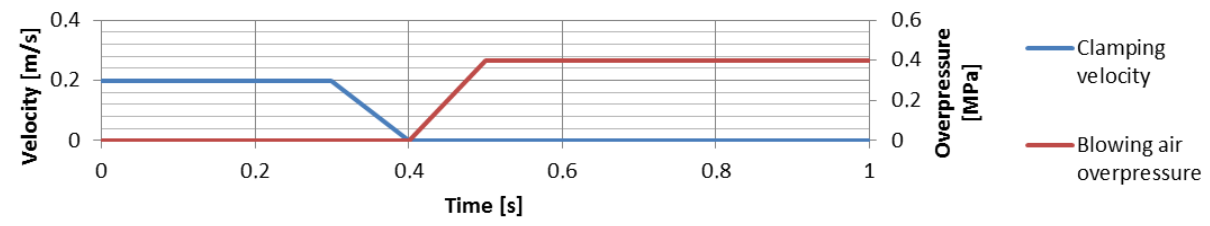

Fig. 2. The function of mould closing speed and blowing gas overpressure versus time

This type of container is manufactured very often from high-density polyethylene (PEHD). In this simulation PE-HD Tipelin $6000 \mathrm{~B}$, produced by MOL Petrochemicals was selected. The rheological viscosity curve was determined for this material in the temperature of $160^{\circ} \mathrm{C}$ and in the shear rate range of $0.005 \div 0.5 \mathrm{~s}^{-1}$ using Rheolyst AR $1000 \mathrm{~N}$ rotational rheometer, manufactured by TA Instruments. The average value of viscosity in this shear rate range is $56.4 \cdot 10^{3} \mathrm{~Pa} \cdot \mathrm{s}$. The density of this material in the liquid state is $0.770 \mathrm{~g} / \mathrm{cm}^{3}$ in the temperature of $160^{\circ} \mathrm{C}$. The density was determined using pvT100 device.

The diameter of the extruded parison was $130 \mathrm{~mm}$. Its initial thickness was computed by Parison Programming module of ANSYS Polyflow software. Some initial simulations were conducted to obtain this thickness. It was assumed that the minimal thickness of the 
canister should be no less than $0.6 \mathrm{~mm}$. The thickness distribution of the parison along its height is shown in Fig. 3.

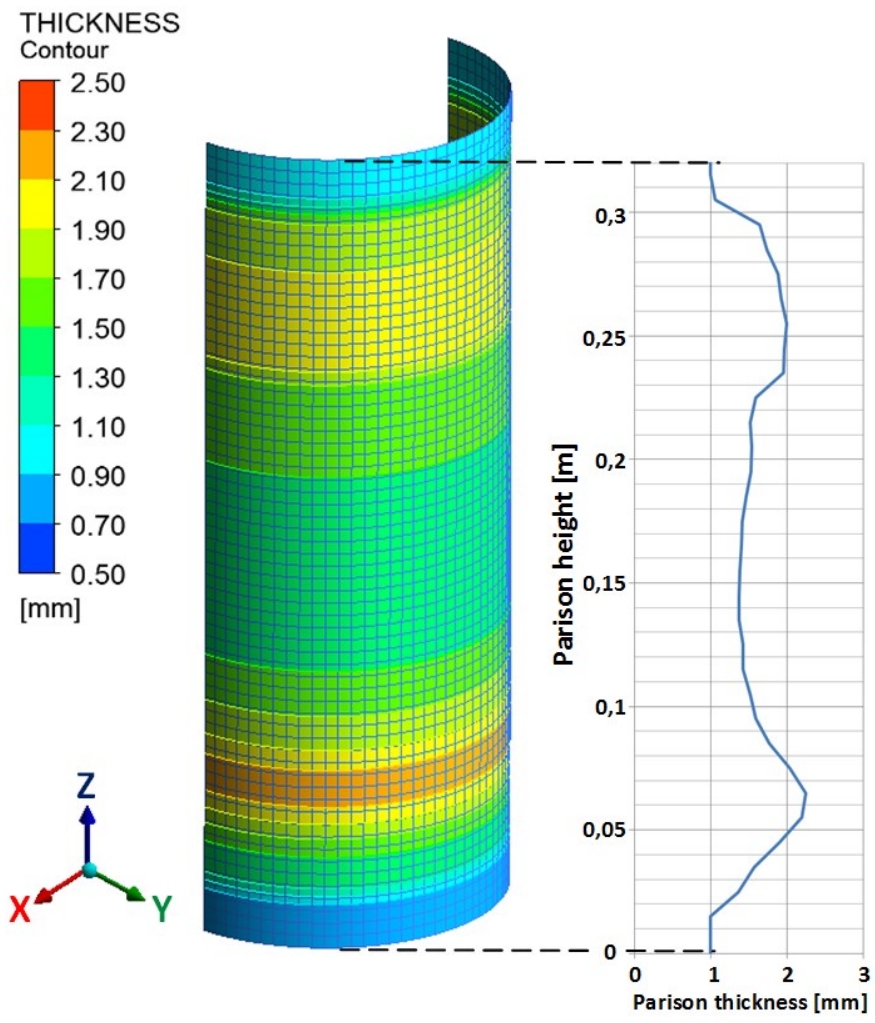

Fig. 3. Parison dimensions - wall thickness distribution

The boundary conditions were imposed on the horizontal and vertical edges of the parison. The condition on vertical edges involves plane symmetry with a normal vector directed along $\mathrm{Y}$ axis. The direction of $\mathrm{Y}$ axis corresponds to the direction of the mould closing and opening. The boundary condition on the horizontal edges is defined by zero value of: the normal velocity and the force tangent to the plane containing the horizontal parison edge. Between the finite elements of the parison and mould mesh a contact condition was imposed. The contact is applied when the distance between the nodes of these meshes is smaller than $0.4 \mathrm{~mm}$.

The size of the parison mesh finite elements is $5 \mathrm{~mm}$, which means the distance between the nodes. The mesh modifier Mapped Face Meshing was used to obtain even distribution of nodes, without mesh deformation. Adaptive Meshing function was also applied to achieve good mesh quality in the handle area. This function is used to increase the number of finite elements (mesh density) when:

- the distance between a node of the parison mesh and a node of the mould mesh expression $1+\left(\frac{d}{B}\right)^{2}$ from the equation (1) - is smaller than the defined value,

- the radius of the parison mesh curvature - expression $A \cdot r+C$ is of a small value.

The maximum number of mesh divisions equal 2 was assumed. The mesh elements are divided when: 


$$
n e w \_s i z e=\max \left\{\text { size_min, }(A \cdot r+C) \cdot\left[1+\left(\frac{d}{B}\right)^{2}\right]\right\}
$$

where:

- $\quad$ size_min - minimum size of an element in the parison $-1.6 \mathrm{~mm}$ was assumed for computations,

- A - fraction of the radius of curvature -0.2 was assumed,

- B - typical distance when mesh is begun to refine - value of $5 \mathrm{~mm}$,

- $\mathrm{C}$ - coefficient of proportionality - the assumed value was 0 ,

- $\mathrm{d}$-distance between node $\mathrm{E}$ of a mesh parison and the nearest node $\mathrm{N}$ of a mesh of the mould,

- $\mathrm{r}$ - local radius of curvature at node $\mathrm{N}$ [14].

The simulation results of blow moulding - the distribution of the canister wall thickness is shown in Fig. 4. The thickness distribution of the product - canister is homogeneous, except of some small thin areas in the handle and some thicker wall below the neck by the parting plane. This proves that distribution of the initial parison thickness was well determined.
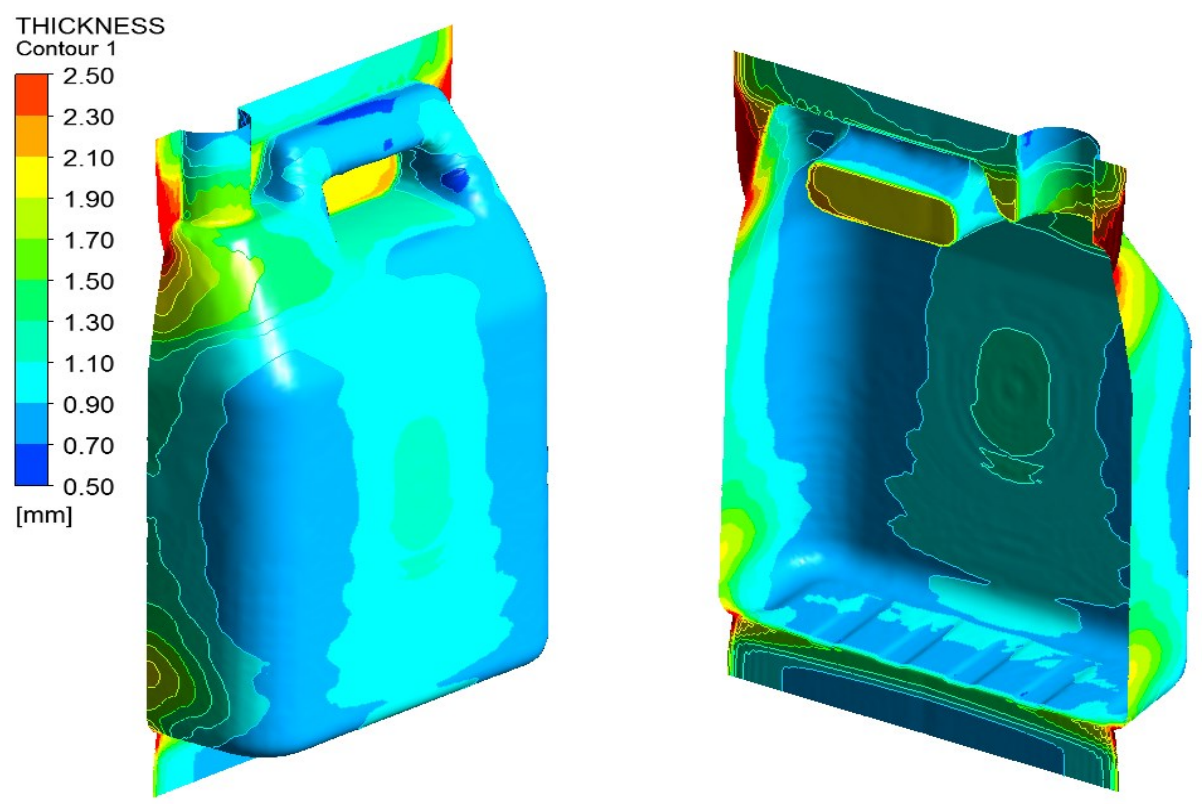

Fig. 4. Blow moulding simulation result

\subsection{Computer simulation of the loaded product}

The model was supplemented with two plates to simulate the load. The plate on the bottom of the canister is imposed with fixed support condition and the plate on the top is loaded with $100 \mathrm{~N}$ concentrated force, directed down along the axis Z-. The value of $100 \mathrm{~N}$ acts on one canister when being transported in the bottom layer, below two other layers of these products filled with water. This is an usual condition of the transport of such products. The numerical calculations were conducted for two cases. In the first case a load caused by hydrostatic pressure was not taken into account, but in the second case it was. 
The contact condition was defined between the bottom surface of the canister and the upper surface of the bottom plate as well as between the upper surface of the handle together with the upper edge of an inlet and a bottom surface of the upper plate.
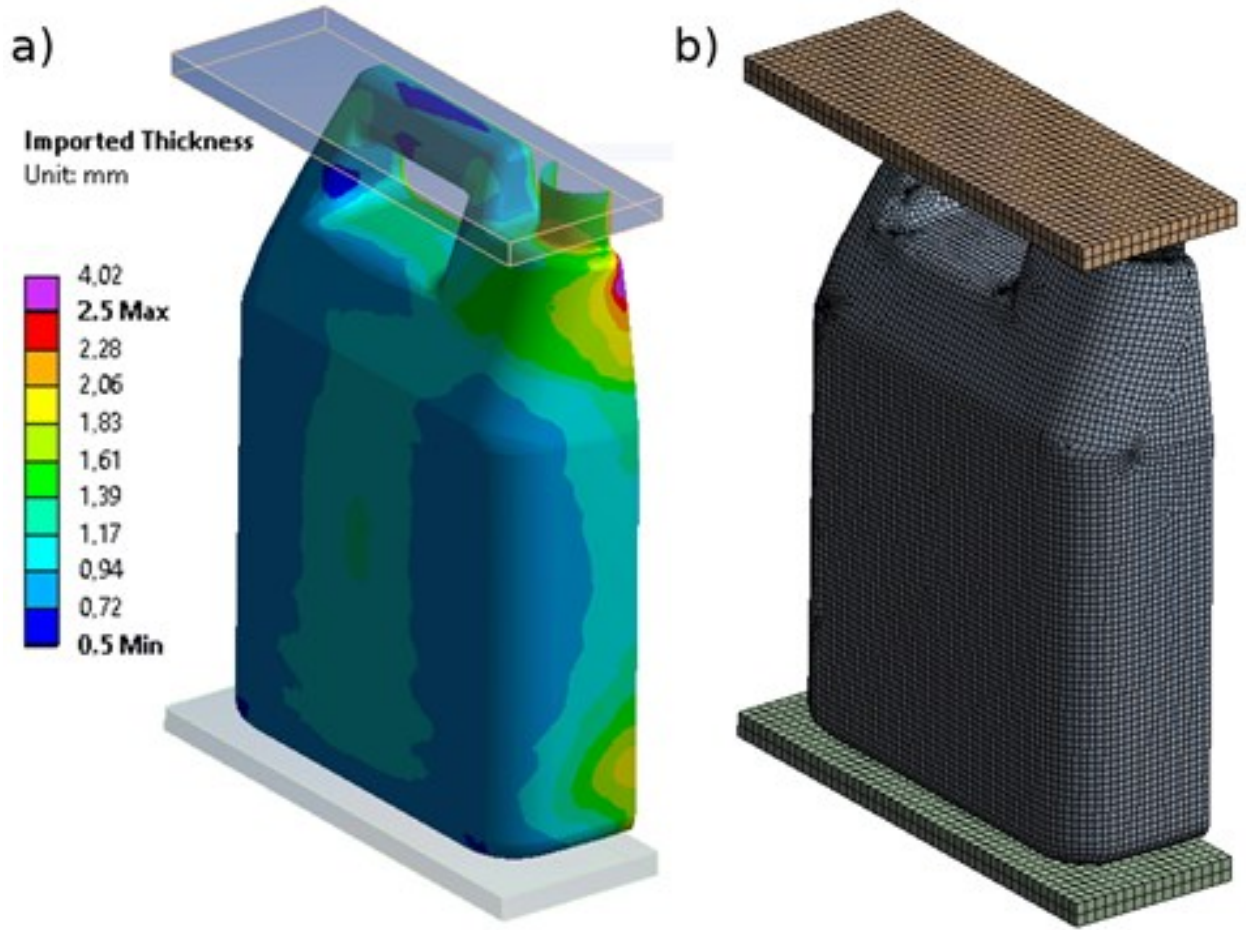

Fig. 5. Preparing load simulation a) mesh used for the load simulation, b) canister wall thickness distribution imported from ANSYS Polyflow solver

For the numerical computations of the load test the surface model with the additional thickness parameter was involved. The thickness values of the container were imported from a text file, generated during the parison blow moulding simulation in Polyflow solver. The thickness distribution after the blow moulding process computer simulation is presented in Fig. 5a. The thickness value was generated inside the canister so the outer surface of the container was unchanged. After mapping of the thickness 3D finite element mesh can be generated. The average size of the container mesh edges was equal $3 \mathrm{~mm}$, after adding a mesh modifier (Body Sizing) to the canister model. The mesh is shown in Fig. 5b.

\subsection{Results of computer simulation of the load}

The numerical simulation results of the load test were: stress distribution and ready product deformation, computed for two cases:

- canister loaded by a vertical force equal $100 \mathrm{~N}$,

- canister loaded by a vertical force equal $100 \mathrm{~N}$ and the internal walls loaded by hydrostatic pressure resulting from filling the container by a liquid.

Loading the designed canister with the vertical force equal $100 \mathrm{~N}$ causes that the stress is created in the product. The stress distribution is shown in Fig. 6. The maximum value equals $9.13 \mathrm{MPa}$ and occurs in the area below the inlet. A big stress values are also in the zone of the vertical walls of the canister handle. 


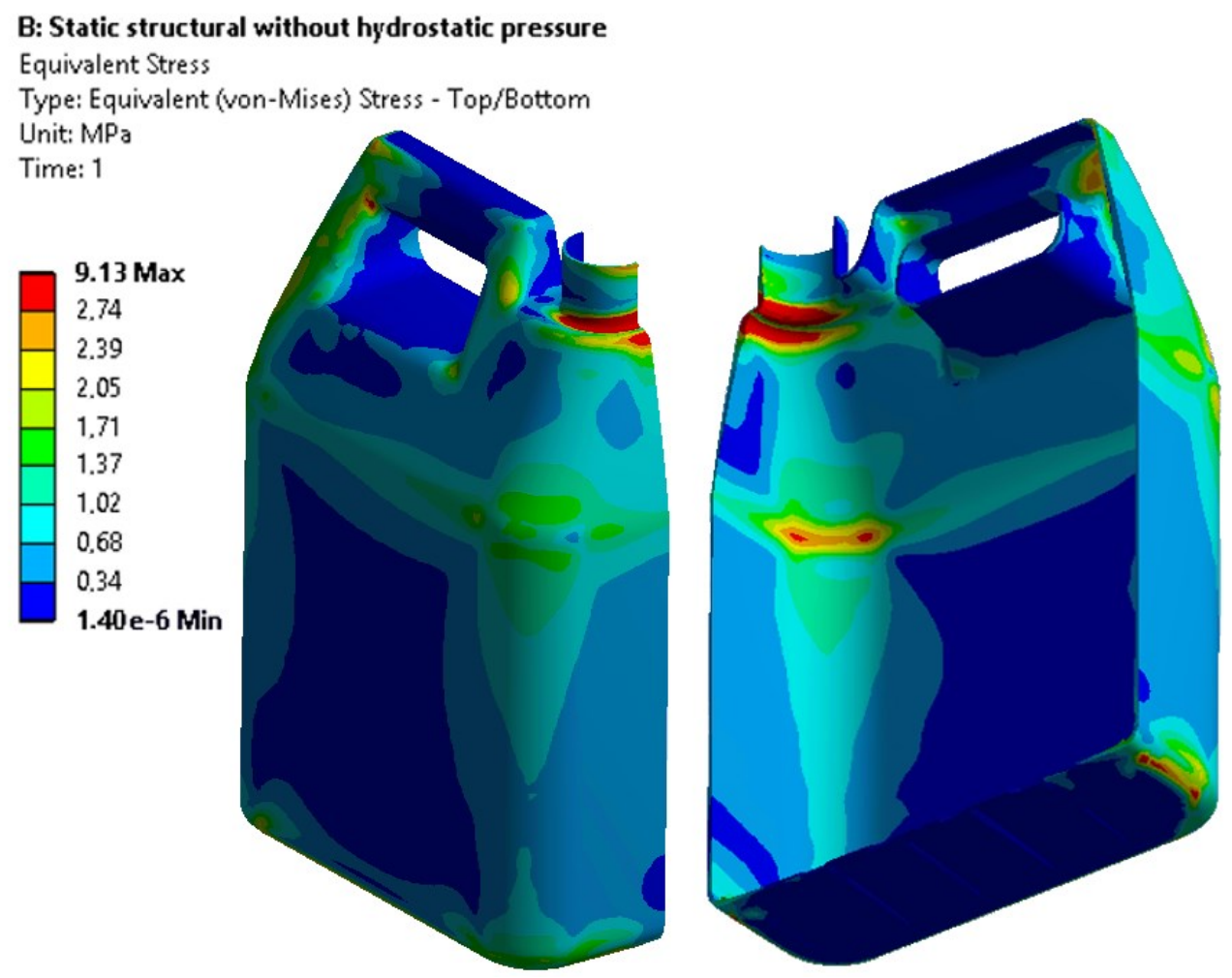

Fig. 6. Distribution of the stress without hydrostatic pressure (Equivalent Stress)

The canister deformation caused by the vertical force of $100 \mathrm{~N}$ is presented in Fig. 7. This force causes the biggest displacement of the rear wall in a place where the vertical surface changes into the handle wall at $11^{\circ}$ angle. A significant deformation occurs also in the analogical zone on a front wall. 

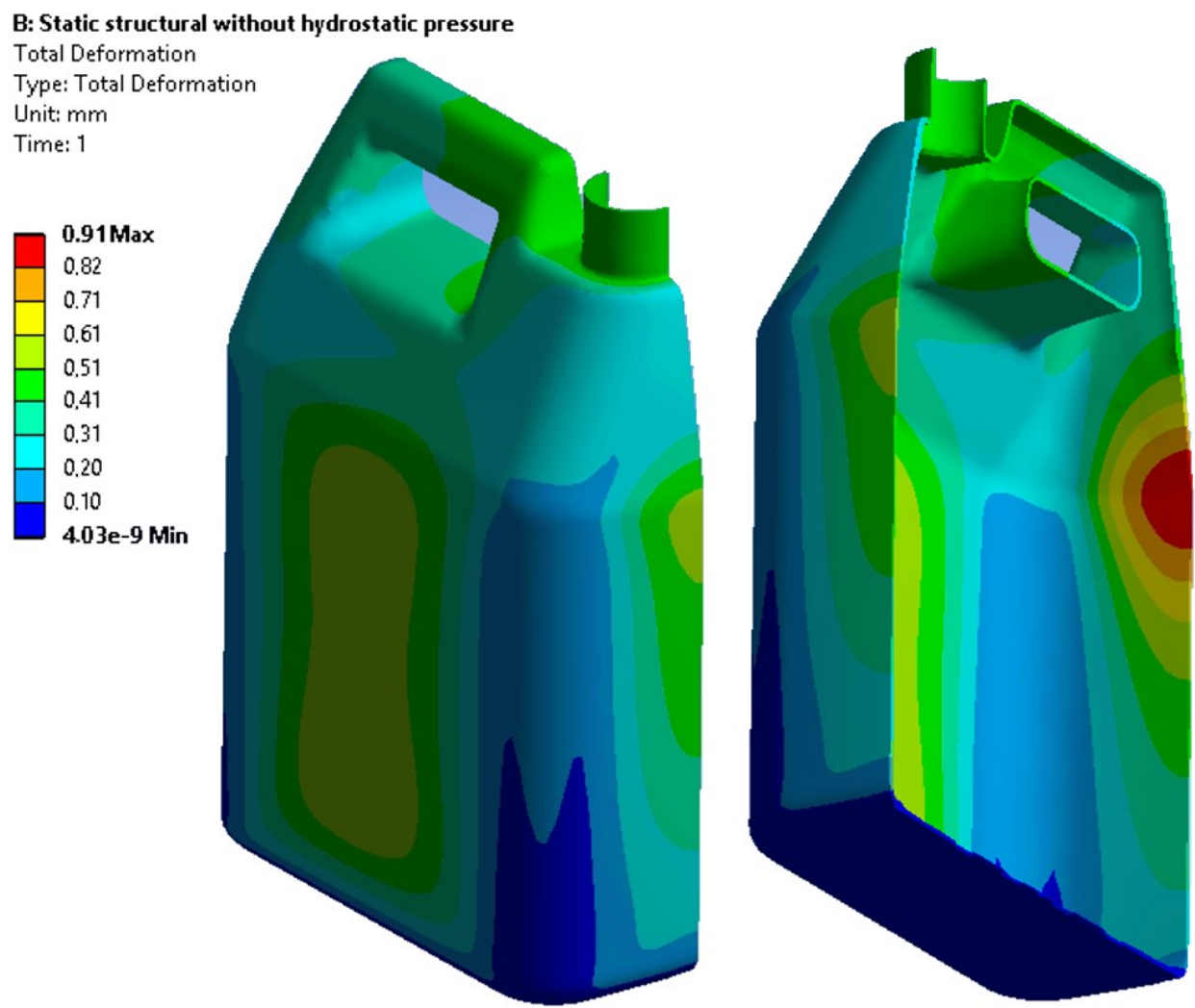

Fig. 7. Strain distribution - real scale (Total Deformation)

After adding a load resulting from hydrostatic pressure the maximum value of the stress increased by $19 \%$. In this case the side walls of the canister are much more loaded - see Fig. 8 compared with Fig. 6. The maximum stress value calculated occurs in the bottom zone of the side walls.

The maximum value of stress equal 10.9 MPa does not exceed the maximum tensile strength at yield, declared by the manufacturer of this plastic: $32 \mathrm{MPa}$ [15]. In order to predict whether the canister wall can be thinner than this obtained from the current simulation some numerical simulation of dynamical loads should be done. 


\section{Equivalent Stress Unit: $\mathrm{MPa}$ \\ Time: 1

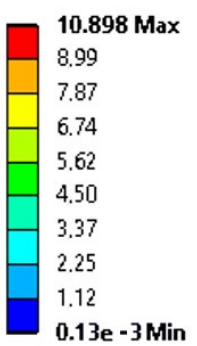

C: Static structural with hydrostatic pressure

Type: Equivalent (von-Mises) Stress - Top/Bottom
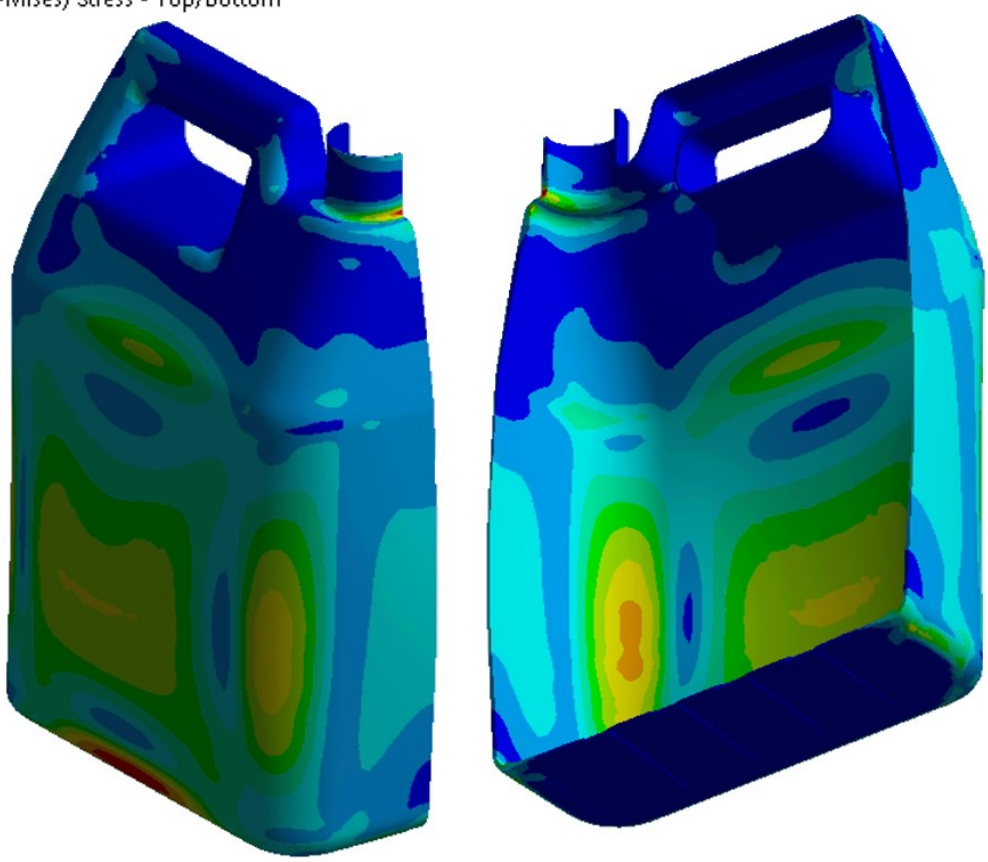

Fig. 8. Stress calculated considering hydrostatic pressure (Equivalent Stress)

Filling the canister with a liquid causes a large deformation of this product in the side wall zone and also in a zone of front and back vertical walls (Fig. 9). The displacement values caused by the vertical force are relatively small in comparison to the displacement values caused by the hydrostatic pressure. 


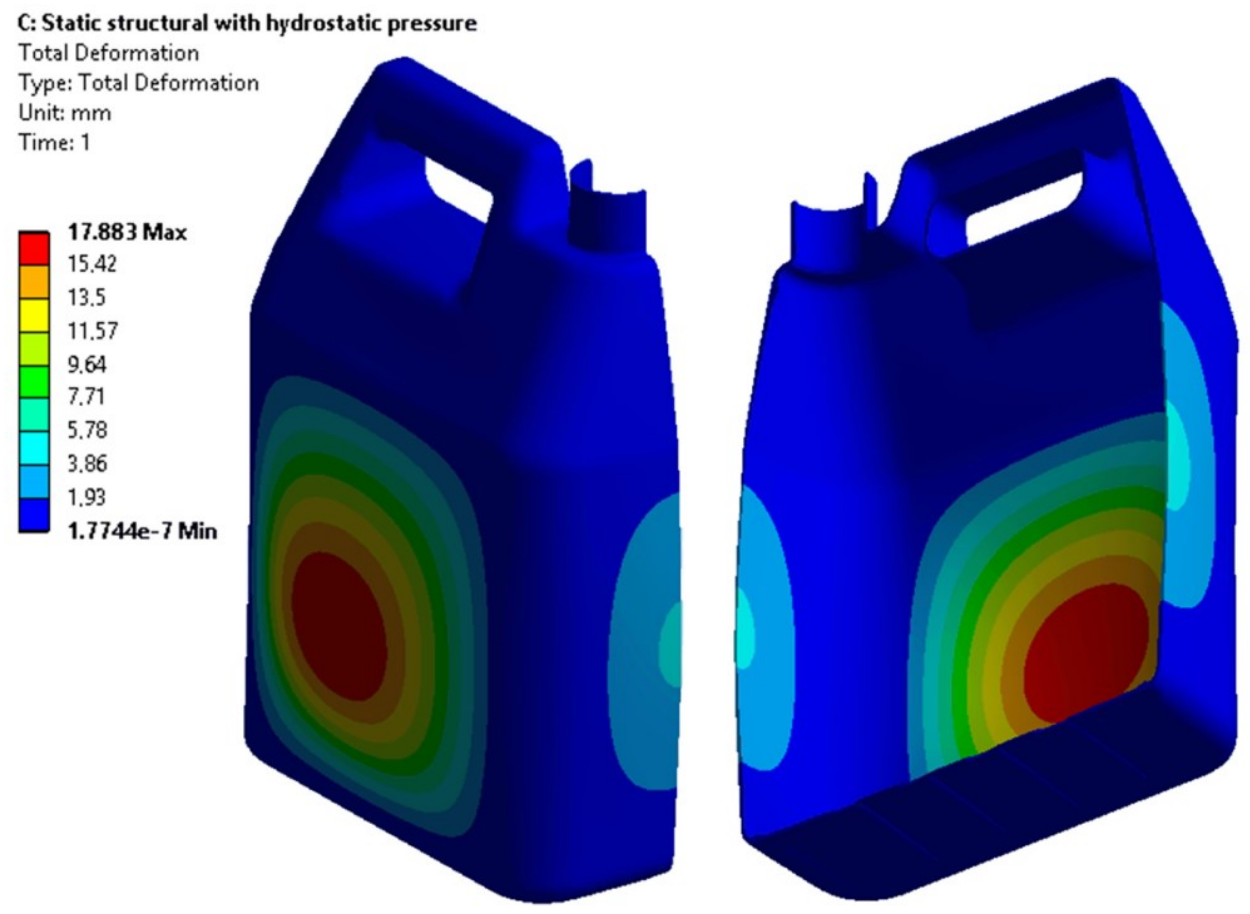

Fig. 9. Total deformation - in three axes directions

\section{Conclusions}

A study of a combined computer simulation was presented in this article. The mechanical strength simulation of a canister-type plastic container loaded with a compression force was made, but based on the results of the simulation of manufacturing this product by blow moulding - on the base of the wall thickness distribution result, since the wall thickness impacts the local product strength.

Results of numerical calculations of strength made using the data coming from he simulation of manufacturing process allow obtaining more accurate data, important regarding the predicted quality of a new product. Using the results of polymer processing simulation for strength calculations improves the quality of forecasting the properties of plastics products.

On the base on the computer simulation study the following conclusions can be drawn:

- simulation of the extrusion blow moulding process allows predicting many properties of a designed product which is going to be manufactured. A key result of this simulation is the distribution of the product wall thickness,

- using results of the polymer processing simulation further in mechanical strength computer simulation enables stress and strain analysis of a designed product without making real tests, and eliminating the problems with incorrect product design,

- contemporary computer simulation programs allow making virtual analyses concerning each aspect of the plastic product lifetime - starting from a shape design, through usage properties prediction up to the product utilization. 
The authors wish to thank Department of Polymer Engineering and Technology from Wrocław University of Science and Technology for the rheological measurements and Department of Polymer Processing from Lublin University of Technology for p-v-T measurements.

\section{References}

1. H. Meetwall, Virtual prototyping for the blow molding industry. (ANSYS U.S.A. 2012)

2. S. Tanoue, T. Kajiwara, K. Funatsu, K. Terada, M. Yamabe, Numerical Simulation of Blow Molding - Prediction of Parison Diameter and Thickness Distributions in the Parison Formation Process. Polym. Eng. Sci. 36, 2008-2017 (1996)

3. S. I. Tanifuji, Overall Numerical Simulation of Extrusion Blow Molding Process. Polym. Eng. Sci. 40, 1878-1893 (2000)

4. K. Pepliński, M. Bieliński, Polyflow software use to optimize the parison thickness in blowing extrusion. Journal of POLISH CIMAC. R. 4 (3), (2009)

5. C. Gauvin, F. Thibauld, D. Laroche, Optimization of Blow Molded Part Performance through Process Simulation. Polym. Eng. Sci. 43, 1407-1414 (2003)

6. Y. Fukuzawa, S. Tanoue, Y. Iemoto, R. Kawachi, H. Tomiyama, Three-dimensional simulation on multi-layer parison shape at pinch-off stage in extrusion blow molding. Polym. Eng. Sci. 50, 1476-1484 (2010)

7. J. C. Yu, X. X. Chen, T. R. Hung, F. Thibauld, Optimization of extrusion blow molding processes using soft computing and Taguchi's method. J. Intell. Manuf. 15, 625-634 (2004)

8. M. Modławski, J. Nabiałek, T. Jaruga, Symulacja odkształcenia wyrobu rozdmuchowego o stałej i zmiennej grubości ścianki. Tworzywa Sztuczne w Przemyśle 34, 94-97 (2016)

9. D. Kwiatkowski, M. Modławski, T. Jaruga, Symulacje komputerowe grubości ścianki butelki uzyskiwanej $w$ procesie wytlaczania $z$ rozdmuchiwaniem. Przetwórstwo Tworzyw 21, 256-261 (2015)

10. P. Klein, F. Fradet, H. Meetway, T. Marchal, Virtual Prototyping Applied to a BlowMolded Container. (Proceedings of SPE ANTEC, Orlando, Florida, U.S.A., 2012)

11. K. Pepliński, M. Bieliński, Wpływ warunków przetwórstwa na wybrane wskaźniki użytkowe wytworów wyttaczanych $z$ rozdmuchiwaniem. (Postęp w przetwórstwie materiałów polimerowych, Ed. J. Koszkul, E. Bociąga, 176-183, Częstochowa 2006)

12. D. V. Rosato, A. V. Rosato, D. P. DiMattia, Blow Molding Handbook. (Hanser Publishers, Munich, 2004)

13. K. Pepliński, Problem raczki. Jak wyeliminować problemy $w$ procesie wyttaczania $z$ rozdmuchiwaniem podczas formowania raczek pojemników?. Plastics Review 71-72, 46-47 (2007)

14. ANSYS Polyflow help documents (2017)

15. TIPELIN 6000B Technical Data Sheet - MOL Petrochemicals: https://mol.hu/en/polymers/products/hdpe-medium-and-high-density-polyethylene, (Access: 07.2017) 